\title{
Effective Containment of The COVID-19 Pandemic Among Migrants and Refugee: World Health Organization
}

\section{Göçmenler ve Mülteciler Arasında COVID-19 Salgınının Etkili Bir Şekilde Kontrol Altına Alınması: Dünya Sağlık Örgütü}

\author{
Saurabh RamBihariLal Shrivastava ${ }^{* 1}$, Prateek Saurabh Shrivastava ${ }^{2}$
}

\begin{abstract}
The ongoing Corona Virus Disease-2019 (COVID-19) pandemic continues to advance with each day and it is worth noting that no individual, community, population group or nation is immune to the infection. Migrants and refugees constitute a vulnerable population group and this calls for the urgent need to include migrants and refugees in the action plan made for the containment of the infection and ensure that no compromises are made with regard to their right to attain the highest levels of physical \& mental health. In conclusion, it is very clear that if we want to overcome the threat of the COVID-19 pandemic, we will be needing a whole-of-community approach, partnerships with various sectors, which essentially includes the inclusion of migrants and refugees. The need of the hour is to extend all the prevention and control activities to the vulnerable population groups and ensure that the risk of acquisition or transmission of infection can be minimized.
\end{abstract}

Keywords: COVID-19 pandemic, Migrants, Refugee, World Health Organization

\section{ÖZET}

Devam eden Corona Virüsü Hastalığı-2019 (COVID-19) pandemisi her gün ilerlemeyi sürdürmektedir hiçbir birey, toplum, nüfus grubu ya da ulusun enfeksiyona karșı bağışık değildir. Göçmenler ve mülteciler savunmasız bir nüfus grubunu olușturmaktadır ve bu durum, göçmenlerin ve mültecilerin enfeksiyonun kontrol altına alınması için yapılan eylem planına acil olarak dahil edilmesini ve en üst düzeyde fiziksel ve ruhsal sağlığa ulaşma haklarından ödün verilmemesini gerektirmektedir. Sonuç olarak, COVID-19 salgını tehdidinin üstesinden gelmek istiyorsak, temel olarak göçmenleri ve mültecileri içeren, çeşitli sektörlerle ortaklıkların yapıldığı, toplumun tamamı yaklaşımına gereksinim duyacağımız çok açıktır. Şu an gereksinimimiz, tüm önleme ve kontrol faaliyetlerini savunmasız nüfus gruplarına yaymak ve enfeksiyonun yakalanması ya da bulaşma riskinin en aza indirgenmesini sağlamaktır.

Anahtar Kelimeler: COVID-19 salgını, Göçmenler, Mülteci, Dünya Sağlık Örgütü

Received date / Geliş tarihi: 19.04.2020, Accepted date / Kabul tarihi: 03.05 .2020

${ }^{1}$ Member of the Medical Education Unit and Institute Research Council, Department of Community Medicine, Shri Sathya Sai Medical College \& Research Institute, Sri Balaji Vidyapeeth (SBV) - Deemed to be University, Ammapettai, Nellikuppam, Chengalpet District, Tamil Nadu 603108, INDIA.

${ }^{2}$ Department of Community Medicine, Shri Sathya Sai Medical College \& Research Institute, Sri Balaji Vidyapeeth (SBV) - Deemed to be University, Ammapettai, Nellikuppam, Chengalpet District, Tamil Nadu - 603108, INDIA.

*Address for Correspondence / Yazışma Adresi: Saurabh RamBihariLal Shrivastava, Professor, Department of Community Medicine, Shri Sathya Sai Medical College \& Research Institute, Sri Balaji Vidyapeeth (SBV) - Deemed to be University, Tiruporur - Guduvancherry Main Road, Ammapettai, Nellikuppam, Chengalpet District, Tamil Nadu - 603108, INDIA.

E-mail: drshrishri2008@gmail.com

Shrivastava SR, Shrivastava PS. Effective Containment of The COVID-19 Pandemic Among Migrants and Refugee: World Health Organization. TJFMPC, 2020;14(2): 163-165.

DOI: $10.21763 /$ tjfmpc.723032 


\section{INTRODUCTION}

The ongoing Corona Virus Disease-2019 (COVID19) pandemic continues to advance with each day and it is worth noting that no individual, community, population group or nation is immune to the infection. Till date, 2160207 cases and 146088 deaths have been attributed to the infection, which amounts to a global case fatality rate of $6.76 \%{ }^{1}$

\section{Migrants and Refugee - Vulnerable population}

Migrants and refugees constitute a vulnerable population group and are exposed to a significantly higher risk of acquiring the infection, as they stay in overcrowded settings with poor ventilation, limited access to water supply and sanitation facilities, minimal number of employment opportunities (which compels them to go out in search of work), and have questionable access to the health-care services or other welfare measures. ${ }^{2}$,

${ }^{3}$ Further, it is important to note that migrants have been excluded in many nations from national programs directed towards the improvement of health or financial protection schemes and thus it makes the entire process of early detection, testing, treatment, contact tracing for the novel viral infection extremely difficult and challenging. ${ }^{2}$

\section{COVID-19 infection: Public health perspective}

However, from the public health perspective, it is an alarming concern as these population groups are very much at risk to acquire the infection and thereby the possibility of transmission of infection increases enormously. This calls for the urgent need to include migrants and refugees in the action plan made for the containment of the infection and ensure that no compromises are made with regard to their right to attain the highest levels of physical $\&$ mental health. In addition, these population groups should have an equitable access to health care without any discrimination and it should be offered to them in a gender-sensitive, culturallysensitive manner both in the health centers as well as in their workplace settings. ${ }^{2}$

\section{Planned strategies}

The delivery of the quality assured services to these population cannot be accomplished unless we bring about reforms in the overall coordination and process of planning, wherein the health needs of migrants \& refugees have to be merged with the general population and thus while planning for preparedness for the novel infection, we should consider them. ${ }^{2,} 4$ It has to be ensured that the testing facilities for the infection should be offered free to them so that no financial barrier prevents them from availing health care and it is extremely important to strengthen this aspect as the undiagnosed person will continue to transmit the infection to their contacts. ${ }^{4}$ Moreover, as it might be difficult for the government authorities to reach these population groups owing to the shortage of health professionals because of the challenges posed by the pandemic, it is ideal to develop linkages with non-governmental agencies or establish international cooperation for migrants staying near national boundaries to enable the reach of services to migrants and refugees. ${ }^{2}$

Special attention should be given towards strengthening of surveillance activities to enable detection of every single case from these vulnerable populations. ${ }^{4}$ In-fact, all the suspects should be tested for the infection and if found positive; should be isolated and given appropriate treatment, while the contacts should be quarantined. Further, the importance of infection control practices cannot be ignored and steps should be taken to orient them about what needs to be done to reduce the risk of acquisition or transmission. ${ }^{2,} 4$ In general, measures should be taken to improve the hygiene practices of the community as a whole and it includes investment for strengthening their water supply and sanitation services. Moreover, while all this is being done, the provision of other essential health services keeping in mind the needs of migrants and refugees (like treatment for tuberculosis, HIV, chronic illnesses, etc.) should also, be continued. ${ }^{2}$

As some of the migrants and refugees have to go across borders in the search of their livelihood, it is extremely important to strengthen the screening practices at different points of entry and offer them without any stigmatization. At the same time, it should be advised for them to avoid unnecessary travel and look for options within their own settings. ${ }^{2}, 5$ Considering that the knowledge and awareness about the infection among these population groups will be not good, it is extremely important to strengthen the risk communication mechanism and inform them about the disease, modes of transmission, symptoms, ways to prevent the transmission and where to approach, if they develop symptoms. ${ }^{2,4}$ It is of utmost importance to get their total cooperation in all the measures planned and implemented by the public health authorities to contain the infection. Finally, as workplace can turn out to be an important location for acquisition or exaggeration of the infection, under all circumstances, the migrants and refugees should be given access to infection prevention and control measures, mental support, occupational health services, and adequate access to water, sanitation and hand washing facility by the employers. ${ }^{2,4}$ 


\section{CONCLUSION}

In conclusion, it is very clear that if we want to overcome the threat of the COVID-19 pandemic, we will be needing a whole-of-community approach, partnerships with various sectors, which essentially includes the inclusion of migrants and refugees. The need of the hour is to extend all the prevention and control activities to the vulnerable population groups and ensure that the risk of acquisition or transmission of infection can be minimized.

\section{REFERENCES}

1.World Health Organization. Coronavirus disease 2019 (COVID-19) Situation Report - 89; 2020. Available from: https://www.who.int/docs/defaultsource/coronaviruse/situation-reports/20200418sitrep-89-covid-19.pdf?sfvrsn=3643dd38 2 [Last Accessed on 2020 Apr 19].

2.World Health Organization. Preparedness, prevention and control of coronavirus disease (COVID-19) for refugees and migrants in non- camp settings - Interim guidance. Geneva: WHO press; 2020. p: 1-4.

3.World Health Organization, UNICEF. Water, sanitation, hygiene, and waste management for the COVID-19 virus. Geneva: WHO press; 2020. p: 1 4.World Health Organization. 2019 Novel Coronavirus (2019-nCoV): Strategic preparedness and response plan. Geneva: WHO press; 2020. p: 1-20.

5. Shrivastava SR, Shrivastava PS. Minimizing the risk of international spread of coronavirus disease 2019 (COVID-19) outbreak by targeting travelers. J Acute Dis. 2020;9(2):47-8.

Conflicts of interest: All authors - none to declare.

Author contributions: SRS contributed in the conception or design of the work, drafting of the work, approval of the final version of the manuscript, and agreed for all aspects of the work. PSS contributed in the literature review, revision of the manuscript for important intellectual content, approval of the final version of the manuscript, and agreed for all aspects of the work. 